Z. Klin. Chem. Klin. Biochem.

11. Jg. 1973 , S. $501-505$

\title{
Immunological Determination of Human Fetal Hemoglobin
}

\author{
By Hiromitsu Tamachi \\ Department of Biochenistry (Director: Prof. Dr. H. Hirai) Hokkaido University School of Medicine, Sapporo, Japan
}

(Eingegangen am 1. August 1973)

\begin{abstract}
A new method is described for the immunological determination of human fetal hemoglobin (HbF) using specific antiserum. Whole blood is pretreated with an alkaline reagent to denature and remove adult hemoglobin ( $\mathrm{HbA}$ ) and other non hemoglobin proteins, leaving $\mathrm{HbF}$ in solution. $\mathrm{HbF}$ is then determined by single radial immunodiffusion. The specificity, accuracy and high sensitivity of the method wcre found to be satisfactory. The HbF concentration in normal individuals and patients was determined by this method.
\end{abstract}

Es wird ein neues immunochemisches Verfahren für die Bestimmung von menschlichem fötalen Hämoglobin mittels spezifischen Antiserums beschrieben. Das Probenblut wurde mit einem alkalischen Reagenz behandelt, mit dem Erwachsenen-Hämoglobin und andere Eiveiße außer dern fötalen Hämoglobin denaturiert und von der Lösung ausgeschlossen wurden. Dann wurde der Gehalt des fötalen Hämoglobins in der Lösung durch die cinfache radiale Immunodiffusion bestimmt. Die Spezifität, Genauigkeit und Empfindlichkeit der Methode war genügend. Fötales Hämoglobin von Gesunden und Kranken wurde mit der vorliegenden Methode bestimmt.

It is well known that $\mathrm{HbF}$ increases in some hematologic diseases, including leukemia $(1,2,3)$, hypoplastic anemia $(4,5)$, and thalassemia $(6,7)$. The clinical significance of this observation and the mechanism of the change from fetal to adult hemoglobin synthesis is of interest.

The one minute alkali-denaturation method of SINGER et al. (8) has been widely used for the determination of $\mathrm{HbF}$, but there are some problems concerning the specificity of this determination. Many other methods for the determination of $\mathrm{HbF}$, such as chromatographic $(9,10)$, spectrographic (11) and amino acid analytical methods (12) have been reported, but these procedures are rather complex and their accuracy is not satisfactory, especially at low concentrations of $\mathrm{HbF}$.

For these reasons, we have attempted to develop a new method for the determination of $\mathrm{HbF}$ based on an antigen-antibody reaction which is highly specific and sensitive compared with SINGER's method. The level of $\mathrm{HbF}$ in some blood specimens from normal individuals and some patients was determined by this new method.

\section{Experiments and Results}

Preparation of Antigen

HbF solution was prepared from cord blood by CHERNOFF's method (13), and further purified by Amberlite CG-50 column chromatography according to the method of ALLEN et al. (14) to remove non-hemoglobin proteins (15), which would interfere with the production of specific antiserum against $\mathrm{HbF}$. A partially purified solution of $\mathrm{HbF}(5 \mathrm{ml}, 40 \mathrm{mg} / \mathrm{ml})$ was applied to a column $(3 \times 30 \mathrm{~cm})$ of Amberlite CG-50 equilibrated with $0.04 \mathrm{~mol} / 1$ sodium phosphate buffer, $\mathrm{pH} 6.9$ containing $0.01 \mathrm{~mol} / 1 \mathrm{KCN}$, and eluted with the same buffer at a flow rate of $40 \mathrm{ml}$ per hour.

Optical density of fractions was measured at $415 \mathrm{~nm}$ as shown in Figure 1. Under these conditions, fraction I, II and III were obtained. Non-hemoglobin protein in these fraction was identified electrophoretically (Fig. 2) and verified using a precipitin reaction with antisera against non-hemoglobin proteins. Electrophoresis was carried out according to the method of Rosenbaum (16). The non-hemoglobin protein was prepared by the method

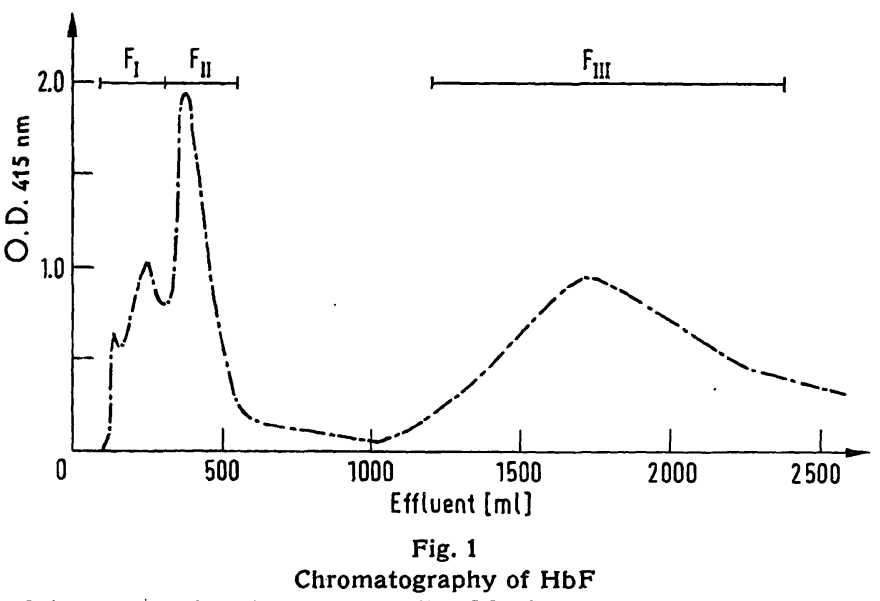

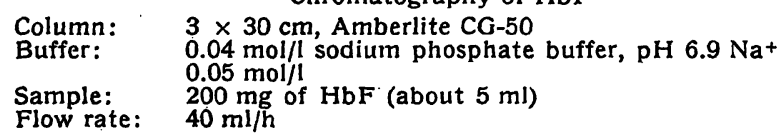

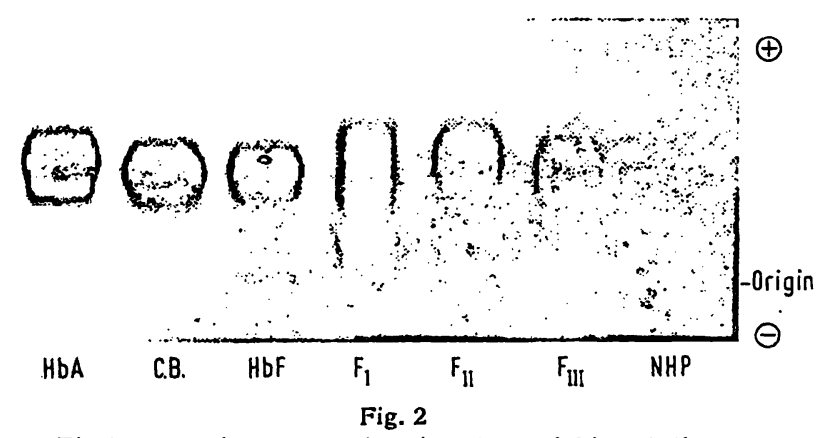

Electrophoretic pattern of various henuglobin solutions Supporting media: Cellulose acetate membrane Buffer: Tris-EDTA-borate buffer $\mathrm{pH} 9.0$ Current time: $\quad 0.6 \mathrm{~mA} / \mathrm{cm} 40 \mathrm{~min}$ Staining: Ponceau 3R

Sample HbA: Hemolysate of normal adult blood C.B: Hemolysate of cord blood

HbF: $\quad H b F$ purified by CHERNOFF's method NHP: $\quad$ Fon hemoglobin protein 
of WinsLow et al. (17). All these fractions contained $\mathrm{HbF}$ but the non-hemoglobin protein was found only in fraction I. Fraction II and III were collected as purified $\mathrm{HbF}$ and used as the antigen.

\section{Production of Antisera}

The Antigen solution ( $\mathrm{HbF}$ : about $20 \mathrm{mg} / \mathrm{ml}$ ) was mixed with an equal volume of FREUND's complete adjuvant and 2 to $2.5 \mathrm{ml}$ of the mixture containing 20 to $25 \mathrm{mg}$ of $\mathrm{HbF}$ was injected subcutancously into a rabbit's back once a week for 4 to 6 weeks. The rabbits were periodically bled from marginal ear veins and the scra were collected for precipitin tests. At 10 to 14 days after the last injection, the blood was obtained from the Arteria carotis. The antigen-antibody reaction was studied with the double diffusion technique in agar according to the method of OuCHTERLONY (18). The antigens tested were normal human serum, nonhemoglobin proteins, $\mathrm{HbA}_{0}, \mathrm{HbA}_{2}$, hemolysate of cord blood, $\mathrm{HbF}$ prepared according to CHERNoff's method, and the chromatographed fractions mentioned previously. $\mathrm{HbA}_{0}$ and $\mathrm{HbA}_{2}$ were prepared according to the method of WinsLow et al. (17).

The result is shown in Figure 3. The precipitin lines showed that there were no antigenic differences with respect to the antiserum used between $\mathrm{HbA}_{0}$ and $\mathrm{HbA}_{2}$, and also between $\mathrm{HbF}$, its fractions and hemolysate of cord blood. The precipitin line due to $\mathrm{HbA}_{0}$ (or $\mathrm{HbA}_{2}$ ) and that due to $\mathrm{HbF}$, however formed a "spur", indicating partial antigenic identity of $\mathrm{HbA}_{0}$ and $\mathrm{HbF}$. This appears to be due to the $\alpha$-chain which is common to both $\mathrm{HbA}_{0}$ and $\mathrm{HbF}$. Therefore, the antibody against $\alpha$-chain in the antiserum was absorbed by purified $\mathrm{HbA}_{2}$ solution since it was easily obtained free of $\mathrm{HbF}$. After absorption of antiserum with $\mathrm{HbA}_{2}$, the antiserum reacted only with $\mathrm{HbF}$ and its fractions, demonstrating that it was specific for $\mathrm{HbF}$ as indicated in Figure 4.

\section{Immunological determination $\mathrm{HbF}$}

An $\mathrm{HbF}$ solution prepared by means of CHERNOFF's method as mentioned previously was serially diluted with saline and used for standardization. The gels for immunodiffusion were prepared

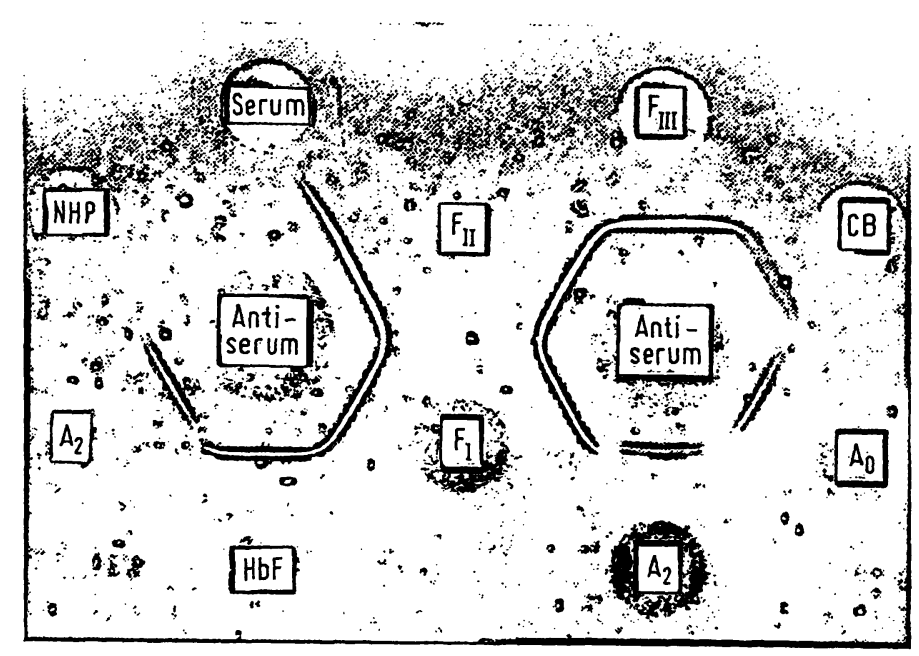

Fig. 3

\begin{tabular}{ll}
\multicolumn{3}{c}{ Precipitin reaction of anti-HbF serum in agar gel } \\
Antiserum: & Rabbit antiserum against $\mathrm{HbF}$ \\
NHP: & Non hemoglobin protein \\
C. $\mathrm{B}$ : & Cord blood hemolysate \\
FI-IIJ: & Fraction of HbF from Amberlite CG-50 \\
$\mathrm{A}_{0}:$ & $\mathrm{HbA}_{2}$ \\
$\mathrm{~A}_{2}:$ & $\mathrm{HbF}_{2}$ purified by CHERNOFF's method \\
HbF: & $0.5 \mathrm{mg} / \mathrm{ml}$
\end{tabular}

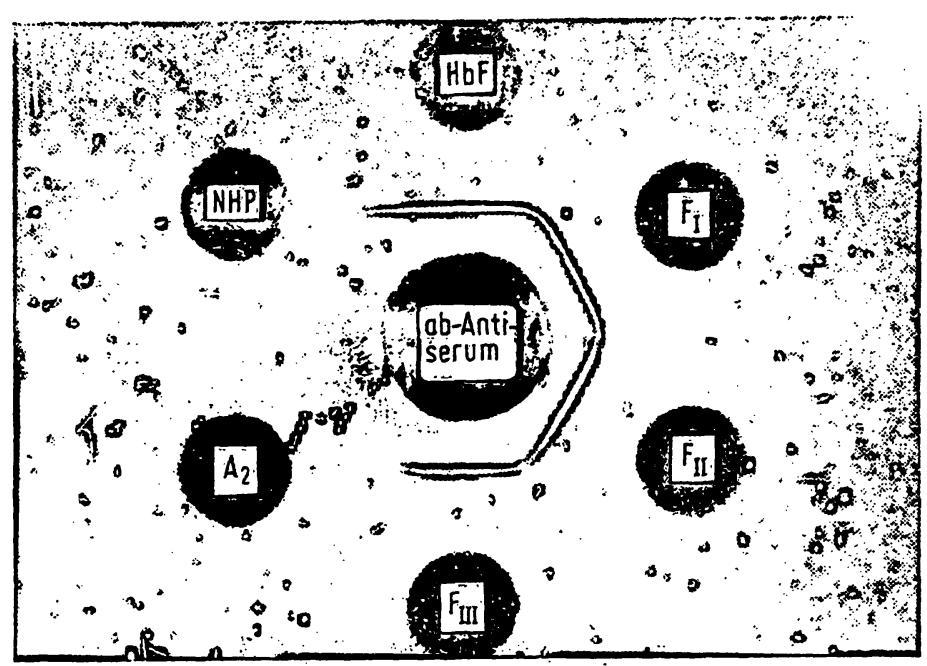

Fig. 4

Precipitin reaction of absorbed anti-HbF serum in agar ge! Nomenclature is the same as Fig. 3

ab-Antiserum: Anti-HbF serum absorbed with $\mathrm{HbA}_{2}$

in Petri dishes with $0.4 \mathrm{ml}$ of antiserum mixed with $9.6 \mathrm{ml}$ of $1.2 \%$ agarose-saline solution. Single tadial immunodiffusion was carried out according to the method of MANCINr et al. (19), and the squared diameters of precipitin rings were plotted as a function of antigen concentration.

A linear relation between antigen concentration. and the squares of the diameters of precipitin rings was observed as shown in Figure 5. The sensitivity of this method was $20 \mathrm{mg} \mathrm{HbF} / \mathrm{ml}$ and the calibration range was 20 to $600 \mathrm{mg} / \mathrm{ml}$.

Interference with the $\mathrm{HbF}$-anti $\mathrm{HbF}$ antibody reaction by $\mathrm{HbA}$

Though the specific antiserum reacted only with $\mathrm{HbF}$, it was found that the precipitin rings yielded by hemolysates from normal individuals or patients were so obscure that the measurement of the diameter of rings was difficult. In order to understand the reason for this obscurity of the precipitin ring, various amount of purified $\mathrm{HbA}$, non-hemoglobin proteins or serum were

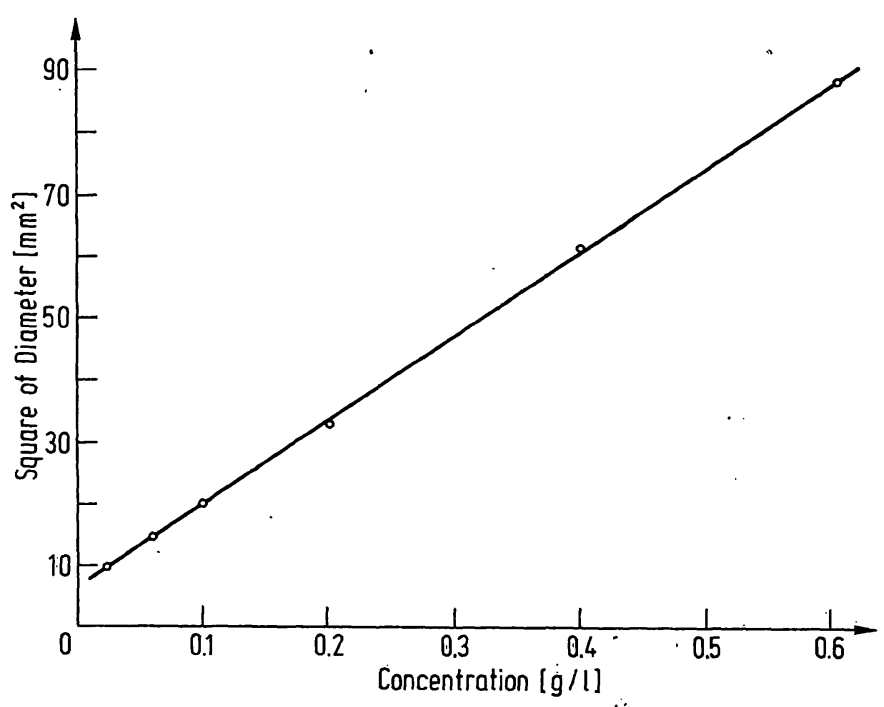

Fig. 5

Calibration curve of $\mathrm{HbF}$ by precipitin reaction

Agar gel in the Petri dish contained of $0.4 \mathrm{ml}$ antiserum and $9.6 \mathrm{ml}$ Agar gel in the Petri dish contained of $0.4 \mathrm{ml}$ antiserum and $9.6 \mathrm{ml}$
$1.2 \%$ Agarose-saline. Each standard solution of $\mathrm{HbF}$ is subjected to
immunodiffusion for 24 to 36 hours 
added to the solution of definite amounts of purified $\mathrm{HbF}$, and these mixtures were subjected to the single radial immunodiffusion procedure. It was evident that $\mathrm{HbA}$ interfered with the precipitin reaction and the obscurity of the precipitin rings was observed when the content of $\mathrm{HbA}$ in the mixtures was more than twice that of HbF. The non-hemoglobin proteins and serum did not affect the precipitin ring. Why $\mathrm{HbA}$ interferes with the precipitin reaction of $\mathrm{HbF}$ is not clear. Thus it is necessary to remove HbA from the sample bemolysates prior to immunodiffusion.

\section{Determination of $\mathrm{HbF}$}

\section{Pretreatment of the blood specimen}

Blood was obtained from normal individuals and patients using either $3.8 \%$ sodium citrate or heparin as anticoagulant. Prior to immunodiffusion, the blood specimens were treated directly with alkaline reagent according to CHERNOFF's method (13) to remove $\mathrm{HbA}$ and proteins other than $\mathrm{HbF} ; 2$ volumes of whole blood were mixed with 16 volumes of $1 / 12 \mathrm{~mol} / 1 \mathrm{NaOH}$ solution for various times at $20^{\circ} \mathrm{C}$ and then the reaction was stopped with 9 volumes of saturated $\left(\mathrm{NH}_{4}\right)_{2} \mathrm{SO}_{4}$ solution containing $9.5 \mathrm{ml}$ of conc. $\mathrm{HCl}$ per 1 .

After a few minutes, the reaction mixtures were centrifuged at 3000 r. p. m. for $10 \mathrm{~min}$ to obtain the supernatant as shown in Figure 6. $4 \mu \mathrm{l}$ of the supernatant was subjected to single radial immunodiffusion for 24 to $36 \mathrm{~h}$ and the amount of $\mathrm{HbF}(\mathrm{g} / \mathrm{l})$ was calculated from the calibration curve.

When the specimen was reacted with alkaline reagent for more than one minute, the precipitin rings were clear, showing that most of $\mathrm{HbA}$ in blood was removed and its inhibitory effect of formation of precipitin ring was eliminated. Moreover the longer the reaction time with alkaline reagent, the smaller the precipitin ring. This indicated that $\mathrm{HbF}$ was also denatured by the alkaline reagent though its denaturation rate was very low. When the logarithms of the amounts of $\mathrm{HbF}$ estimated at various intervals were plotted against the reaction time, straight lines were obtained in all specimens containing various amount of $\mathrm{HbF}$ as shown in Figure 7. This observation indicated that the alkalidenaturation of $\mathrm{HbF}$ was "pseudo" first order reaction. By extrapolating the straight line to zero time, the quantity of $\mathrm{HbF}$ in the specimens can be estimated. The slope of the lines showed practically the same value

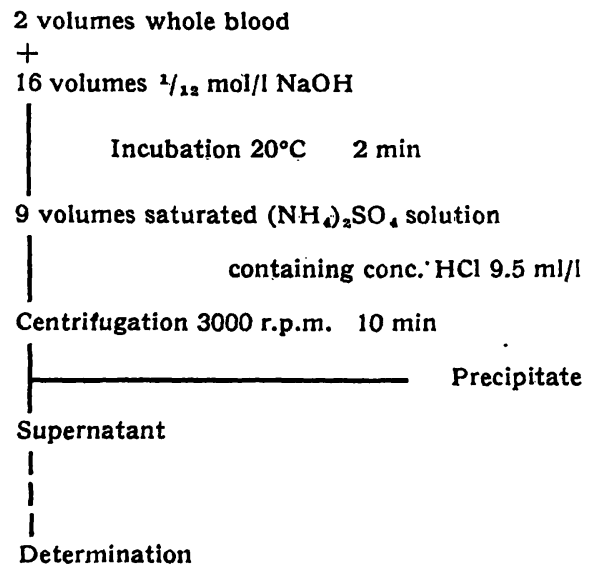

Fig. 6

Alkali-treatment of blood specimen for determination of $\mathrm{HbF}$

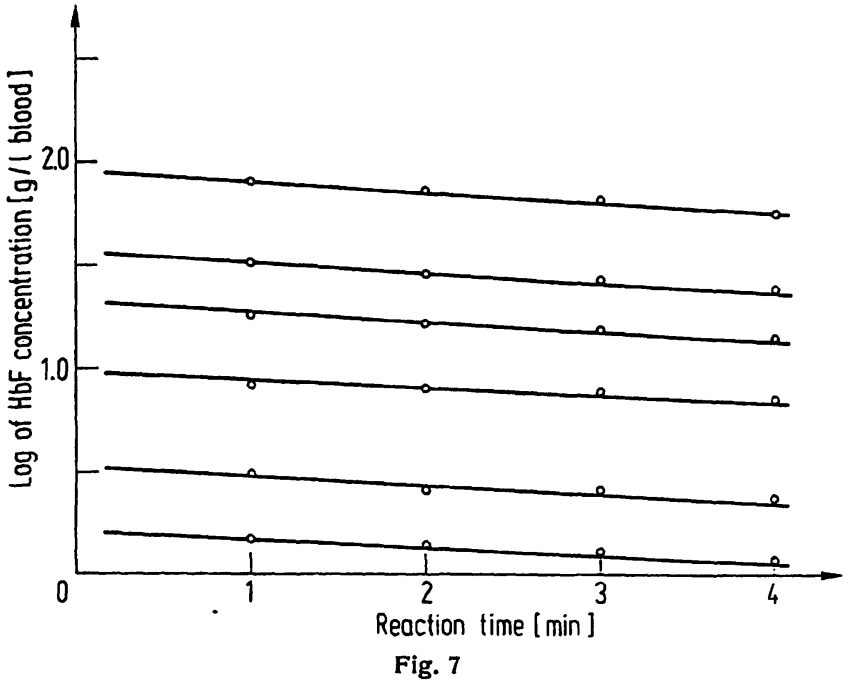

Rate of alkali denaturation of $\mathrm{HbF}$ in blood

The bloods which contained various amounts of $\mathrm{HbF}$ were prepared by mixing normal adult blood and cord blood. The procedure for the alkali
denaturation is the same as in Fig. 6 except for the reaction time $k=3.50( \pm 0.14) \cdot 10^{-2}\left[\mathrm{~min}^{-1}\right](\bar{x} \pm \mathrm{s})$

regardless of the concentration of $\mathrm{HbF}$ in the range from 0.03 to $13.5 \%$. The mean value of the slope was

$$
3.50( \pm 0.14) \times 10^{-2} / \mathrm{min}
$$

From this value, the following equation was obtained. $\log \mathrm{x}_{0}=\log \mathrm{x}_{\mathrm{t}}+3.5 \times 10^{-2} \cdot \mathrm{t}$ or $\mathrm{x}_{0}=10^{3.5 \times 10^{-2} \times \mathrm{t}} \cdot \mathrm{x}_{\mathrm{t}}$ Where $x_{0}$ is the amount of $\mathrm{HbF}(\mathrm{g} / \mathrm{l})$ at zero time and $x_{t}$ is that at $t$ min.

\section{Practical procedure for determination of $\mathrm{HbF}$}

The amount of $\mathrm{HbF}$ was determined using the same procedure described above and calculated by the following equations.

$$
\begin{gathered}
a=10^{3.5} \times 10^{-2} \times 2 \cdot x_{2}=1.175 \cdot x_{2} \\
\operatorname{HbF}(\%)=\frac{a \times 13.5}{\text { total hemoglobin }} \times 100
\end{gathered}
$$

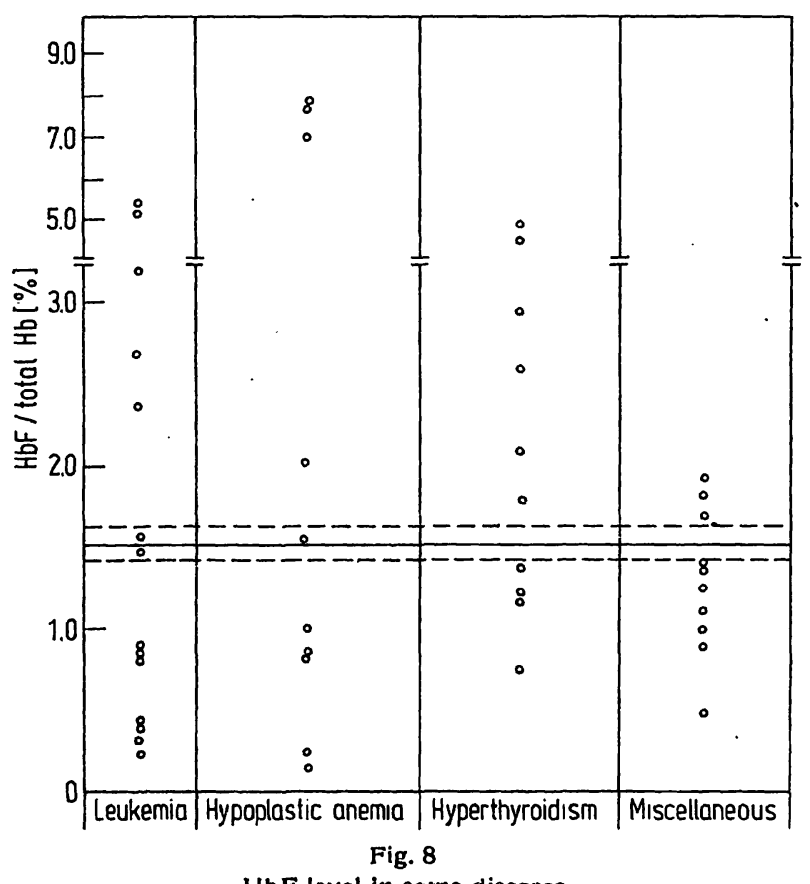

HbF level in some diseases

The dotted lines define the values for normal adults: $\overline{\mathrm{x}} \pm \mathrm{s}=1.53 \pm 0.06 \%$ 
Where, $a$ is the concentration of $\mathrm{HbF}$ at zero time, $\mathbf{x}_{2}$ is the concentration of $\mathrm{HbF}$ measured after 2 min of alkali treatment, $\mathrm{HbF} \%$ is the percent total hemoglobin measured by the cyanmethemoglobin method.(20), and 13.5 is the reagent dilution factor. The time of alkali treatment was chosen such that satisfactory amounts of $\mathrm{HbA}$ would be eliminated, that the loss of $\mathrm{HbF}$ should be avoided and also that the reaction time should be as short as possible: $2 \mathrm{~min}$ for the alkali treatment satisfied these conditions. The reproducibility of the determination was examined by repeated testing of the same sample, giving a test error of $\pm 3 \%$.

$\mathrm{HbF}$ levels in some diseases

The percent concentration of $\mathrm{HbF}$ in total hemoglobin was determined using this method for blood samples from normal individuals and patients with leukemia, hypoplastic anemia, hyperthyrodism and other diseases. The results are shown in Figure 8. In some cases, high values of $\mathrm{HbF}$ were observed, but the clinical significance is not yet clear.

\section{Discussion}

For this method, the preparation of monospecific antiserum against $\mathrm{HbF}$ is essential. Hitherto, $\mathrm{HbF}$ as an antigen solution was purified by means of CHERNOFF's method, but this method fails to remove all nonhemoglobin proteins which are quite antigenic compared with $\mathrm{HbF}$, so that the antisera obtained contained antibodies against non-hemoglobin proteins as well as $\mathrm{HbF}$. For this reason, $\mathrm{HbF}$ was further purified on an Amberlite CG-50 column to eliminate non-hemoglobin proteins. The purified $\mathrm{HbF}$ preparation, which was practically free of non-hemoglobin proteins, was used as an antigen for immunization of rabbits. The antiserum thus obtained reacted with $\mathrm{HbF}$ and $\mathrm{HbA}$ only, but did not show any reaction with non-hemoglobin proteins. This indicated that this antiserum contained only antibodies against the $\alpha$ and $\gamma$-chains. The antibodies against the $\alpha$-chain were then absorbed by $\mathrm{HbA}_{2}$. This absorbed antiserum was found to be highly specific for $\mathrm{HbF}$, and the antibody titer was satisfactorily high.

The blood specimens were treated directly by the same alkali-denaturation method as that used for the preparation of $\mathrm{HbF}$, for the following reasons. First, $\mathrm{HbA}$ interfered with the precipitin reaction between $\mathrm{HbF}$ and its antibodies, so that $\mathrm{HbA}$ had to be removed from the specimens prior to immunodiffusion. Second, since the purified $\mathrm{HbF}$ used as the immunogen was prepared using the alkali-denaturation procedures, there may be some effect on the antigenicity of $\mathrm{HbF}$.

Therefore, the blood specimens were also treated by the same alkali-denaturation procedure on the ex"pectation that the difference between the antigenic structure of the immunogen and antigen would be minimized. Third, instead of hemolysate, whole blood was directly treated with the alkali reagent, eliminating the time required for preparation of hemolysate.
For the determination of HbF, SINGER's method has been most widely used. Compared with Singer's method, the present method seems to be more specific for $\mathrm{HbF}$ because of the specificity of the antisera against $\mathrm{HbF}$; moreover in SINGER's method, it is possible that some contaminants such as $\mathrm{CO}-\mathrm{HbA}$ and other substances which, are resistant to the alkali reagent might contribute to the absorption at $540 \mathrm{~nm}$. Another advantage of this method is that the time necessary for preparation of hemolysate in SINGER's method is eliminated. The sensitivity of this method is about 20 times greater than that of SINGER's method, since it is possible to determine as little as $20 \mathrm{mg}$ of $\mathrm{HbF}$ per 1 . The values of $\mathrm{HbF}$ determined by this method were compared with those by SINGER's method with the same samples. The present method gave results about $10 \%$ higher than SINGER's method. This difference is greater than expected even taking into account the fact that the amount of $\mathrm{HbF}$ degraded during $1 \mathrm{~min}$ of the alkali treatment in SINGER's method is about 4 percent (21).

A small amount of the alkali-degraded fragment of $\mathrm{HbF}$ may remain in the supernatant. If the absorption at $540 \mathrm{~nm}$ of the this fragment were lower than that of $\mathrm{HbF}$, but its antigenicity were retained, the lower value by SINGER's method would be accounted for. More precise studies are, however, necessary to confirm this conjecture.

Both this new method and SINGER's method rely on the assumption that the denaturation reaction of $\mathrm{HbF}$ by the alkaline reagent is approximately a first order reaction and the rate of the reaction is constant regardless of the concentration of HbF. SINGER et al. (22) reported a different rate of denaturation in some diseases, although these seemed to be rather exceptional. In 1953, CHERNOFF developed the immunological determination method of $\mathrm{HbF}$ based on the relationship between the appearence time of the precipitin rings and the concentration of $\mathrm{HbF}$ in precipitin tubes. However, when the concentration of $\mathrm{HbF}$ in specimens was high, the appearence time of precipitin rings was so short that the error of determination became large, and when the concentration of $\mathrm{HbF}$ was low, the appearence time was over $100 \mathrm{~min}$ (7). For these reasons, the CHernoff's method might not be satisfactory for routine determination. The present method utilizing immunodiffusion is more convenient because the reaction time is short and the determination of 30 to 40 specimens is possible using only one gel, though 24 to $36 \mathrm{~h}$ are needed for the immunodiffusion. Korn et al. (23) reported recently a modified single radial immunodiffusion method for the determination of HbF. In this method, hemolysates, the concentration of which was adjusted to about $100 \mathrm{~g} / \mathrm{l}$, were used, as in SINGER's method, and also Nigrosin staining of the precipitin rings was necessary for detection against the $\mathrm{HbA}$ background and to increase the sensitivity. In the present method, $\mathrm{HbF}$ can be determined with satisfactory sensitivity without resorting to staining or the preparation of an hemolysate. 


\section{Acknowledgement}

The author thanks Prof. Dr. Hidematsu Hrrax for guidance during this work, and Dr. H. B. Haarrlton, ABCC, Hiroshima, Japan for his suggestions for the preparation of this manuscript.

\section{References}

1. Bloom, G. E., Grald, P. S. \& Diamond, L. K. (1966), Pediatrics 38, 295-299. - 2. MrLler, D. R. (1969), Brit. J. Haematol. 17, 103-112. - 3. Ozsoylu, S. \& BALCI, S. (1970), Clin. Pediat. 9, 152-156. - 4. Maurer, H. S., VidA, L. M. \& Honig, G. R. (1972), Blood 39, 778-784. - 5. BLoom, G. E. \& Diamond, L. K. (1968), New Eng. J. Med. 278, 304-307. 6. Lr, F. P., Alter, B. P. \& Nathan, D. G. (1972), Blood 40, 153-162. - 7. Cinernofr, A. I. (1953), Blood 8, 413-421. 8. Singer, K., Chiernoff, A. I. \& Singer, L. (1951), Blood 6, 413-428. - 9. Huisman, T. H. J., Martis, E. A. \& Dozy, A. (1958), J. Lab. Clin. Med. 52, 312-327. - 10. Huisman, T. H. J. \& Meyering, C. A. (1960), Clin. Chim. Acta 5, 103-123. - 11. BeAVEN, G. H. \& WhITe, J. C. (1953), Nature 172, 1006. 12. Schroeder, W. A., Huisman, T. H. J., Sielton, J. R. \& WILson, J. B. (1970), Anal. Biochem. 35, 235-243. - 13.
Chernoff, A. I. (1953), Blood 8, 399-412. - 14. Allen, D.W., Schroeder, W. A. \& Balog, J. (1958), J. Amcr. Chem. Soc. 80 1628-1634. - 15. Haut, A., Cartwrigit, G. E. \& Wintrobe, M. M. (1964), J. Lab. Clin. Med. 63, 279-289. - 16. RosenBAUM, D. L. (1966), J. Amcr. J. Med. Sci. 252, 726-731. 17. Winslow, R. M. \& Ingram, V. M. (1966), J. Biol. Chem. 241, 1144-1149. - 18. Ouchterlony, O. (1958), in Progr. Allerg. 5, S. 1-78, S. Karger Bascl-New York. - 19. Mancinr, G., Carbanara, A. O. \& Heremans, J. F. (1962), Immunochemistry 2, 235-254. - 20. KAMprer, E. J. \& ZiJLSTRA, W. G. (1961), Clin. Chim. Acta 6, 538-544. - 21. Whire, J. C. \& Benven, G. H. (1959), Brit. Med. Bull. 15, 33-39. - 22. Singer, K., Chernofp, A. I. \& Singer, L. (1951), Blood 6, 429-435. 23. Kohn, J. \& Payne, B. V. (1972), J. Clin. Pathol. 25, 830-831.

Dr. H. Tamachi

Dept. Biochem. School of Med. Hokkaido Univ.

Sapporo/Japan 